rence would be particularly difficult to detect in the obligate pathogens of the Peronosporales.

\section{M. GRIFFIN}

Helen N. Perrin

School of Agriculture,

University of Sydney.

1 Gregory, P. H., Trans. Brit. Mycol. Soc., 35, 1 (1952).

2 Jinks, J. L., Proc. Roy. Soc., B, 140, 83 (1952).

3 Langeron, M., and Vanbreuseghem, R., "Précis de Mycologie" (Masson et Cie, Paris, 1952).

4 Pontecorvo, G., Cold Spring Harbor Symp. Quant. Biol., 11, 193 (1946).

5 Turner, Myfanwy, Trans. Brit. Mycol. Soc., 39, 291 (1956).

\section{Occurrence and Function of the Provisional Embryonic Cuticle of a Lepidopteran}

TH.E provisional embryonic cuticle has been noticed in several groups of insects such as Aphidae, Orthoptera, Hemiptera, Neuroptera and some types of Coleoptera ${ }^{2}$. It was, therefore, of interest to note the presence of the provisional embryonic cuticle in the hitherto unreported group of Lepidoptera.

Various roles have been ascribed to the provisional embryonic cuticle. It has been described as acting as an "egg burster" by Wigglesworth and Sikes" and others. It is also regarded by some as affording protection to newly emerged nymphs of grasshoppers when the young ones crawl from the buried egg-pods to the surface.

I believe ${ }^{3}$ that the moulting of the provisional embryonic cuticle in Locustana pardalina, Tenebrio molitor and Dysdercus cingulatus (unpublished work) is due to developmental causes. Moulting is induced in order to synchronize the rate of deposition of cuticle with the development of muscle ends, so that a proper integration between the muscle and the cuticular exoskeleton can take place. The provisional cuticle is precociously formed, in the sense that it is formed at a time when the muscles are not in a position to become attached to it by means of tonofibrils. While the other functional interpretations are certainly valid, there is reason for believing that they are secondary adaptations.

In Attacus ricini (Lepidoptera), the provisional embryonic cuticle was first detected histologically and also with the help of histochemical methods at about eighty hours before emergence. The second or definitive cuticle was secreted soon after the sloughing of the provisional embryonic cuticle. A thorough examination of the development of skeletal muscles showed that the muscle bands were in an early

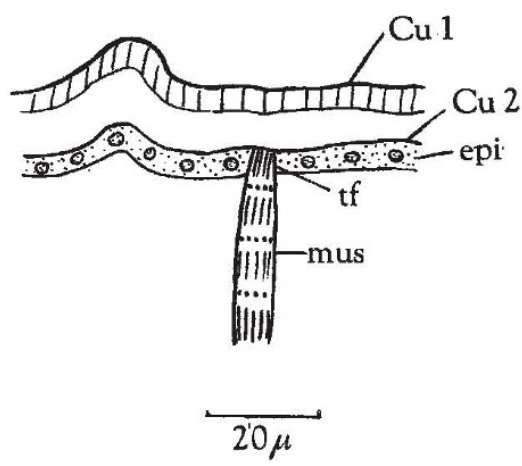

Fig. 1. epi., epidermis ; Cu 1, provisional embryonic cuticle ; $\mathrm{Cu} 2$, definitive cuticle; mus., striated muscle flbre; tf., tono- state of development, mostly in the form of myoblasts at the time of secretion of the provisional embryonic cuticle. The muscles were well formed at the time of the secretion of the definitive cuticle, and it is to this cuticle that the muscles could become properly attached (Fig. 1).

The present investigation on Attacus ricini, therefore, confirms the conclusions reached for Locustana, Tenebrio and Dysdercus.

It is hoped to publish details elsewhere with $\mathrm{Mr}$. Sahani of this Department. Mr. Barkat, of Government Farm, Ranchi, kindly made the eggs available for this work.

R. K. Sharan

Department of Zoology, Science College, Patna, India.

1 Wigglesworth, V. B., "Insect Physiology", second ed. (Methuen, London, 1950).

${ }^{2}$ Sikes, E. K., and Wigglesworth, V. B., Quart. J. Micro. Sci., 79, 165 (1931).

${ }^{3}$ Sharan, R. K., Ann. Zool., 3, 1 (1958); Curr. Sci., 28, 72 (1959).

\section{Incorporation of Acetate into Protein by Obligately Parasitic and Saprophytic Fungi}

The germ tubes of obligate parasites such as the rust fungi and powdery mildews fail to grow in the absence of host plants. This may be caused by metabolic blocks, the general location of which should be revealed by studies on the distribution of radioactive tracer among the various broad classes of metabolites. To determine if this would be a feasible approach to the problem of obligate parasitism, the assimilation of radiocarbon by uredospores of a rust fungus (Uromyces phaseoli (Pers.) Wint.) and conidia of a saprophyte (Aspergillus niger van Tiegh) was studied to see if any important differences in metabolism occurred between them. The preliminary experiments reported here were made with non-germinated spores, so the metabolism studied was essentially catabolic in character.

Spores of the two fungi were compared with respect to their capacities to incorporate the methyl carbon of ${ }^{14} \mathrm{CH}_{3} \mathrm{COONa}$ into sugars, amino-acids, Krebs-cycle acids, proteins, nucleic acids, and lipids. Spores of each species were incubated with $10 \mu \mathrm{c}$. of ${ }^{14} \mathrm{CH}_{3} \mathrm{COONa}$ for various time-periods and then killed with boiling 30 per cent ethanol. Techniques for the separation and analysis of the various components have been described elsewhere ${ }^{1}$.

The results are given in Table 1 and Fig. 1 . The principal differences between the two species occurred in the total activity incorporated and the patterns of

Table 1. Distribution of CARBoN-14 in AMINo-ACIDS From FUnGUS SPORES INCUBATED $10 \mathrm{HR}$. WITH $10 \mu \mathrm{C} .{ }^{14} \mathrm{CH}_{3} \mathrm{COONa}$ $\begin{array}{ccc}\text { Free amino-acids } & \text { Protein amino-aeids } \\ \text { Amino-acid } & \text { U. phaseoli A. niger } & \text { U. phaseoli A. niger }\end{array}$

Alanine

$\gamma$-Aminobutyrat

Arginine

Asparagine

Aspartate

Glutamate

Glutamine

Leucines

Lysine

Prolin

Serine

Threonine

Tyrosin

Total c.p.m. per mgm. N 72,000

Results are given as percentage of total c.p.m. per mgm. protein nitrogen. Detectable label was not found in cysteine, methionine, phenylalanine, histidine or glycine. About 